\title{
Fuzzy Neural Network (FNN) Pada Proses Identifikasi Penyakit ISPA
}

\author{
Dhio Saputra ${ }^{1}$, Musli Yanto ${ }^{1}$, Wifra Safitri ${ }^{2}$, Liga Mayola ${ }^{2}$ \\ ${ }^{1}$ Fakultas Ilmu Komputer, Program Studi Teknik Informatika, Universitas Putra Indonesia YPTK, Padang, Indonesia \\ ${ }^{2}$ Fakultas Ilmu Komputer, Program Studi Sistem Informasi, Universitas Putra Indonesia YPTK, Padang, Indonesia \\ Email: ${ }^{1}$ dhio_saputra@upiyptk.ac.id, ${ }^{2,}{ }^{*}$ musli_yanto@upiyptk.ac.id, ${ }^{3}$ wifrasafitri@upiyptk.ac.id, ${ }^{4}$ ligamayola @upiyptk.ac.id \\ Email Penulis Korespondensi: musli_yanto@upiyptk.ac.id
}

\begin{abstract}
Abstrak-Penyakit ISPA merupakan sebuah penyakit yang dapat menyerang siapa saja mulai dari kalangan balita, anak-anak, remaja, dewasa, bahkan lansia. Penyebab yang dialami oleh penderita penyakit ini cukup sederhana seperti demam, pilek, dan batuk. Pembahasan dalam makalah ini menyajikan sebuah proses identifikasi penentuan penyakit ISPA dengan mengembangkan sebuah model Fuzzy Neural Network (FNN). Proses tersebut akan di optimalisasi menggunakan Logika Fuzzy untuk membentuk aturan proses diagnosis dan kemudian diteruskan dengan Artificial Neural Network (ANN). Model ini dapat memaksimalkan kenerja ANN dalam proses identifikasi sehingga keluaran yang diberikan cukup tepat dan akurat. hasil yang diberikan Logika Fuzzy mampu menggambarkan kejelasan aturan dalam diagnosa dengan menyajikan beberapa aturan (Rule) yang tersaji dari proses Fuzzyfikasi sampai dengan Defuzzyfikasi. Keluaran yang didapat dari proses ANN juga menunjukan hasil yang cukup sempurna dengan hasil nilai rata rata kesalahan berdasarkan MSE sebesar 0.00912 dan nilai akurasi sebesar 91.96\%. Dengan hasil ini, dapat dinyatakan bahwa model FNN dapat digunakan dalam proses diagnosis penyakit ISPA sehingga dalam penyajian makalah ini memiliki tujuan untuk memberikan sebuah alternative dalam proses identifikasi.
\end{abstract}

Kata Kunci: Identifikasi; Penyakit ISPA; Logika Fuzzy; Artificial Neural Network (ANN)

Abstract-ISPA is a disease that can affect anyone from children, adolescents, adults, and even the elderly. The causes experienced by sufferers of this disease are quite simple, such as fever, runny nose, and cough. The discussion in this paper describes the process of ISPA disease identification by developing a Fuzzy Neural Network (FNN) model. The process will be optimized using Fuzzy Logic to form rules for the diagnostic process, then proceed with an Artificial Neural Network (ANN). This model can maximize the performance of ANN in the identification process so that the output given is quite precise and accurate. The results provided by Fuzzy Logic can describe the clarity of the rules in diagnosis by presenting several rules (rules) that are presented from the Fuzzyfication process to the Defuzzyfication process. The output obtained from the ANN process also shows quite perfect results with an average error value based on MSE of 0.00912 and accuracy value of $91.96 \%$. With these results, it can be stated that the FNN model can be used in the ISPA diagnosis process so that the presentation of this paper aims to provide an alternative in the identification process.

Keywords: Identification; ISPA Disease; Fuzzy Logic; Artificial Neural Network (ANN)

\section{PENDAHULUAN}

Penyakit Infeksi Saluran Pernapasan Akut (ISPA) adalah sebuah penyakit yang diakibatkan oleh infeksi yang berada pada saluran pernapasan atas atau bawah manusia[1]. Penyakit ini bukan penyakit biasa, karena penyakit ini dapat menular dan menyebabkan kematian[2]. Berdasarkan fakta, menjelaskan bahwa 20 hingga 30\% dari penderitanya akan mengalami kematian[3]. Dalam hal ini kalangan balita, anak-anak, hingga remaja sangat rentan apabila terjangkit penyakit ini[4],[5]. Untuk dapat mengatasi permasalahan dalam mencegah secara dini maka dibutuhkan sebuah informasi yang dapat menjelaskan tentang gejala dan akibat yang didapat dari penderita penyakit ISPA tersebut. Adapun beberapa langkah antispasi seperti adanya pembahasan penelitian tentang pembangunan sebuah sistem untuk proses diagnosa yang bertujuan sebagai alternative penyajian informasi. Pembahasan yang telah dilakukan oleh (Yuliana, dkk) menjelaskan bahwa sistem yang dibangun dapat digunakan untuk mendiagnosa penyakit ISPA yang diderita dengan menyajikan keluaran dalam bentuk nilai persentase [6],. Dalam kasus penelitian lainya juga menjelaskan bahwa perancangan program dalam menentukan penyakit ispa dapat meningkatkan pelayanan kesahatan bagi masyarakat[7]. Dalam kajian yang hampir sama juga menjelaskan bahwa proses identifikasi dapat dilakukan dengan menggunakan sebuah teknik atau metode teorema bayes untuk melakukan perhitungan statistic dalam menemukan hipotesis untuk diagnose penyakit ISPA[8].

Berdasarkan penjelasan tersebut, dapat dilihat bahwa proses identifikasi dalam penentuan penyakit ISPA sudah banyak dihasilkan namun masih terfokus pada hasil yang diberikan tanpa memperhatikan aturan dalam proses identifikasi. Maka dari itu, dalam penyajian makalah ini, proses identifikasi yang dilakukan akan menyajikan proses yang berbeda dari proses identifikasi sebelumnya. Proses tersebut akan mengembangkan sebuah model dengan mengadopsi konsep Logika Fuzzy dan Artificial Neural Network (ANN) untuk melakukan proses identifikasi. Hasil yang diharapkan dari pengembangan model ini mampu memberikan hasil identifikasi yang optimal. Dilihat berdasarkan penelitian sebelumnya dalam konsep Logika Fuzzy mampu memberikan sebuah solusi dalam pemecahan sebuah masalah[9]. Lebih rincinya menjelaskan bahwa proses identifikasi sebuah penyakit dapat dilakukan dengan menggunakan Logika Fuzzy[10]. Dalam kajian lainnya juga menjelaskan bahwa Logika Fuzzy dapat diterapkan dalam mendiagnosa tingkat resiko kehamilan dengan menyajikan dalam bentuk aturan[11]. Lanjutnya juga menjelaskan bahwa hasil yang diberikan dari Logika Fuzzy dapat melakukan proses identifikasi, penentuan pola, klasifikasi, serta sistem control sebuah sistem[12]. 
Dengan pemaparan dari penelitian Logika Fuzzy sebelumnya diatas, menjelaskan bahwa hasil yang diberikan dari konsep ini memiliki hubungan yang signifikan dengan konsep ANN. Hubungan tersebut terlihat bahwa aturan yang didapat dari pembentukan rule dari proses Fuzzy akan dapat diterapkan pada ANN dalam proses identifikasi. Lebih jelasnya lagi dapat dilihat bahwa basis pengetahuan dari pengembangan model sistem identifikasi berawal dari hasil keluaran proses Logika Fuzzy sehingga ANN akan mampu memproses dan memberikan keluaran yang cukup akurat.

Pada dasarnya Neural Network adalah sebuah metode yang dikembangan dengan proses perhitungan linear untuk menyajikan sebuah solusi dalam memecahkan sebuah masalah[13]. Kemudian dalam penjelasan lainnya, juga mengatakan bahwa Neural Network merupakan sebuah konsep dari Artificial Intelligence (AI) yang mampu digunakan untuk menyelesaikan masalah dengan bentuk perhitungan yang terawasi[14]. ANN merupakan salah satu konsep serta metode yang juga banyak digunakan oleh peneliti sebelumnya dalam proses identifikasi. Kerja dari konsep ini mampu melakukan perhitungan secara matematis dalam menyajikan hasil keluaran. Tidak hanya itu, konsep ini akan dapat melakukan pengujian dari hasil keluaran dengan nilai kesalahan dan nilai akurasi. Berdasarkan penelitian sebelumnya dapat menjelaskan bahwa ANN dapat melakukan proses klasifikasi dengan perhitungan matematis untuk memberikan hasil keluaran yang optimal[15]. Lebih rincinya dapat dijelaskan oleh (Puspaningrum, dkk), menyatakan bahwa ANN dapat melakukan pelatihan dan pengujian jaringan pada proses identifikasi yang akan dilakukan[16]. Dari beberapa penyajian penerapan ANN, menjelaskan bahwa penggunaan konsep ini mampu melakukan deteksi pada penyakit kanker paru dengan tingkat akurasi yang diberikan sebesar 72.97\%[17]. Dalam kasus lainnya, ANN juga mampu mendeteksi penyakit kanker serviks berdasarkan dataset citra sel yang didapat dari penderita[18]. Pada kasus penyakit ISPA, ANN telah digunakan untuk melakukan proses identifiksi dengan memberikan keluaran tingkat akurasi yang didapat sebesar $95.92 \%$ dari gejala yang dialami oleh penderita[19].

Dari pemaparan sebelumnya, maka dapat dilihat bahwa kombinasi kedua konsep yang digunakan dalam model identifikasi yang dikembangkan akan mampu memberikan sebuah proses identifikasi yang jauh lebih baik dari model sebelumnya. Hal ini dapat dibuktikan bahwa Logika Fuzzy dengan ANN akan sangat cocok diterapkan untuk menghasilkan keluaran yang sangat efektif dalam sebuah proses diagnosa. Tujuan pengembangan model ini adalah untuk memberikan sebuah proses identifikasi yang terstruktur dan sistematis sehingga menghasilkan hasil keluaran yang cukup baik untuk menentukan penyakit ISPA. Manfaat yang didapat dari hasil proses identifikasi ini akan dijadikan sebuah solusi alternatif dalam pemberian informasi bagi masyarakat guna pencegahan secara dini agar terhindar dari penyakit ISPA.

\section{METODOLOGI PENELITIAN}

Pada penelitian ini, metodologi penelitian yang digunakan akan tersaji dalam bentuk kuantitatif yang nantinya akan menyajikan proses perhitungan yang bersumber dari data dengan menggunakan konsep serta metode dalam memecahkan sebuah masalah. Proses aktifitas yang akan dilakukan dalam pembahasan penelitian tentang proses identifikasi ini akan digambarkan dengan bentuk kerangka penelitian. Adapun kerangka penelitian dapat digambarkan pada gambar 1 dibawah ini:

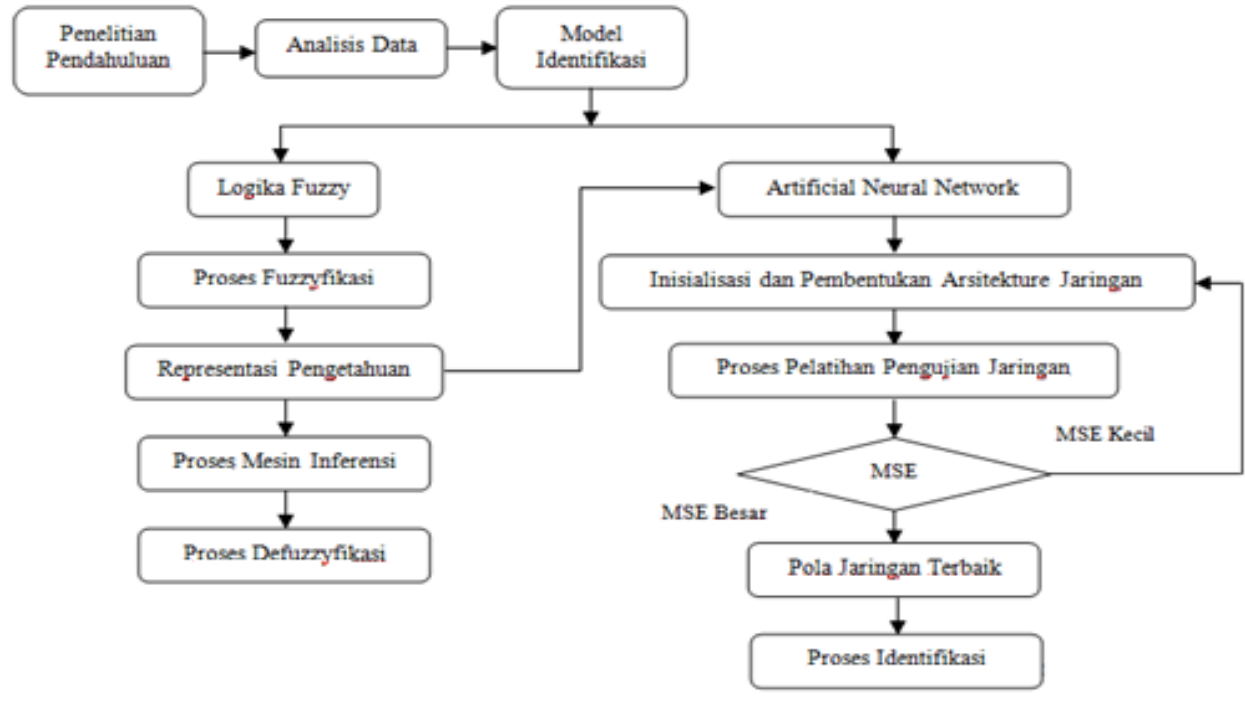

Gambar.1 Kerangka Penelitian

Pada Gambar.1 diatas, dapat dilihat bahwa kerangka penelitian dalam model identifikasi penyakit ISPA menyajikan proses pembahasan dengan menggunakan 2 konsep yakni Logika Fuzzy dan Artificial Neural Netwerk 
(ANN). Proses identifikasi dimulai dengan melakukan analisa pada data yang digunakan, kemudian dilanjutkan pada proses Fuzzy untuk melihat aturan identifikasi yang terbentuk dari representasi pengetahuan. Setelah didapat aturan identifikasi, maka proses dilajutkan untuk pembentukan arsitektur jaringan guna proses pelatihan dan pengujian jaringan. Hasil dari proses ini memberikan pola jaringan yang terbaik dalam proses identifikasi berdasarkan nilai kesalahan MSE.

\subsection{Analisis Data}

Dalam proses identifikasi penyakit ISPA, adapun data yang digunakan adalah data Jenis Penyakit dan data gejala yang didapat dari pakar. Adapun data jenis penyakit ISPA merupakan data primer yang dapat dilihat pada tabel 1 dibawah ini:

Tabel 1. Data Jenis Penyakit ISPA

\begin{tabular}{ccc}
\hline No & Kode penyakit & Jenis Penyakit \\
\hline 1 & P01 & ISPA Ringan \\
2 & P02 & ISPA Berat \\
\hline
\end{tabular}

Pada tabel 1 di atas dapat dilihat bahwa jenis penyakit ISPA memiliki 2 jenis yaitu ISPA Ringan dan Berat. Setelah data jenis penyakit didapat, maka adapun data gejala dapat dilihat pada tabel 2 di bawah ini:

Tabel 2. Data Gejala Penyakit ISPA

\begin{tabular}{ccc}
\hline No & Kode Gejala & Nama Gejala \\
\hline 1 & G01 & Hidung tersumbat \\
2 & G02 & Pilek \\
3 & G03 & Batuk \\
4 & G04 & Sakit tenggorokan \\
5 & G05 & Pegal-pegal \\
6 & G06 & Kelehan \\
7 & G07 & Demam \\
8 & G08 & Sulit bernafas \\
9 & G09 & Pusing \\
10 & G10 & Kehilangan kesadaran \\
\hline
\end{tabular}

Pada tabel 2 di atas, dapat dilihat bahwa ada 10 variabel yang dapat digunakan dalam penentuan penyakit ISPA. Variabel ini nantinya akan diproses dengan logika fuzzy untuk menghilangka noise pada prsoses identifikasi yang dilakukan oleh ANN. Proses ini akan membutuhkan sebuah data set yang digunakan untuk proses pembelajaran dapat dilihat berdasarkan histori data dalam mendiagnosa penyakit ISPA. Adapun data set yang digunakan dapat dilihat pada Tabel.3 berikut ini:

Tabel 3. Data Historis Diagnosa Penyakit ISPA

\begin{tabular}{|c|c|c|c|c|c|c|c|c|c|c|}
\hline $\begin{array}{l}\text { Hidung } \\
\text { tersumbat }\end{array}$ & Pilek & Batuk & $\begin{array}{c}\text { Sakit } \\
\text { Tenggorkan }\end{array}$ & Pegal & Kelelahan & Demam & $\begin{array}{c}\text { Sulit } \\
\text { Bernafas }\end{array}$ & Pusing & $\begin{array}{c}\text { Hilang } \\
\text { Kesadaran }\end{array}$ & Penyakit \\
\hline ya & ya & ya & ya & ya & ya & tidak & tidak & tidak & tidak & Ringan \\
\hline ya & ya & ya & ya & ya & ya & ya & ya & ya & tidak & Ringan \\
\hline ya & ya & ya & ya & ya & ya & tidak & tidak & tidak & tidak & Ringan \\
\hline ya & ya & ya & ya & ya & ya & tidak & tidak & tidak & tidak & Ringan \\
\hline ya & ya & tidak & tidak & tidak & tidak & tidak & tidak & tidak & tidak & Ringan \\
\hline tidak & tidak & tidak & tidak & tidak & tidak & ya & ya & tidak & tidak & Berat \\
\hline tidak & tidak & tidak & tidak & tidak & tidak & ya & ya & tidak & tidak & Berat \\
\hline tidak & tidak & tidak & tidak & tidak & tidak & ya & ya & tidak & tidak & Berat \\
\hline tidak & tidak & tidak & tidak & tidak & tidak & ya & ya & ya & tidak & Berat \\
\hline tidak & tidak & tidak & tidak & tidak & tidak & ya & ya & 55 & tidak & Berat \\
\hline
\end{tabular}

Pada tabel 3 di atas dapat dilihat bahwa proses diangnosa belum mampu memberikan kejelasan dalam menentukan penyakit ISPA. Untuk itu, maka model identifikasi yang diusulkan akan mampu dijadikan sebuah solusi dalam memberikan kejelasan pada proses identifikasi yang akan dilakukan. 


\subsection{Logika Fuzzy}

Logika Fuzzy merupakan sebuah konsep yang memberikan kepastian pada sebuah masalah yang bersifat kabur (Tidak Jelas)[20]. Dalam penjelasan sederhana, Fuzzy dapat menyatakan sebuah kasus yang bernilai salah dan bernilai benar dan dapat juga dinyatakan sebagai sebuah nilai salah dan benar[21]. Dalam proses inferensinya, adapun tahapan Logika Fuzzy dapat dilihat sebagai berikut[22] :

1. Fuzzyfikasi

Proses fuzzifikasi adalah sebuah bentuk proses yang dilakukan untuk mentransformasi sebuah nilai yang digunakan pada proses fuzzy. Hasil perubahan nilai variabel tersebut dapat disebut dengan variabel linguistik tidak hanya merubah nilai variabel saja, namun juga melakukan proses perubahan pada fungsi keanggotaan dalam bentuk sebuah informasi.

2. Pembentukan Basis Pengetahuan

Pembentukan basis pengetahuan dilakukan untuk menentukan jumlah himpunan yang digunakan serta akan berkaitan dengan keluaran yang dihasilkan. Proses yang dilakukan ini akan membentuk sebuah aturan (Rule) sehingga basis pengatahuan ini akan bertindak sebagai control sistem dalam penentuan output.

3. Mesin Inferensi

Mesin Inferensi digunakan untuk memembetuk sebuah mekansisme dalam menghasilkan sebuah jawaban dengan hasil terbaik, aturan yang didapat dari basis pengetauan sebelumnya akan di buat dalam bentuk penulisan IF... Then.

4. Defuzzifikasi

Dalam proses ini, merupakan sebuah proses yang dilakukan untuk mengembalikan nilai semula dari Fuzzyfikasi yang sudah dilakukan.

\subsection{Artficial Neural Network (ANN)}

Merupakan sebuah konsep pengetahuan yang digunakan dalam memecahkan sebuah masalah dengan mengacu pada informasi yang digunakan berdasarkan representasi kinerja otak manusia[23]. Secara lebih jelasnya, ANN adalah salah satu teknik yang mengadopsi sistem kerja otak manusia[24]. Implementasi dari ANN ini sudah banyak digunakan seperti proses identifikasi, klasifikasi, serta prediksi[25]. Proses kerja ANN dapat melakukan proses pembelajaran yang terawasi dengan perhitungan secara linear untuk menghasilkan sebuah keluaran jaringan. Proses tersebut akan diawali dengan sebuah proses transformasi data yang akan digunakan sebelumnya. Adapun proses tranformasi tersebut dapat dilakukan dengan menggunakan Persamaan,1 dibawah ini :

$$
X^{\prime}=\frac{0.8(X-b)}{a-b}+0.1
$$

Setelah proses transformasi data dilakukan sehingga data tersebut dapat digunakan dalam proses ANN, maka proses akan dilanjutkan dalam pembentukan arsitektur jaringan yang terdiri dari lapisan input (Input Layer), lapisan tersembunyi (Hidden Layer) dan lapisan keluaran (Output Layer). pada lapisan input jaringan dalam proses identifikasi menggunakan 10 lapisan neuron yang berasal dari data gejala yang didapat pada prsoses analisa. Untuk lapisan tersembunyi, akan diambil sebanyak 4 lapisan secara awal. Terakhir adalah 1 buah lapisan input untuk keluaran proses identifikasi. Adapun arsitektur jaringan yang digunakan dalam proses identifikasi penyakit pada ISPA dapat digambarkan pada gambar 2 berikut ini:

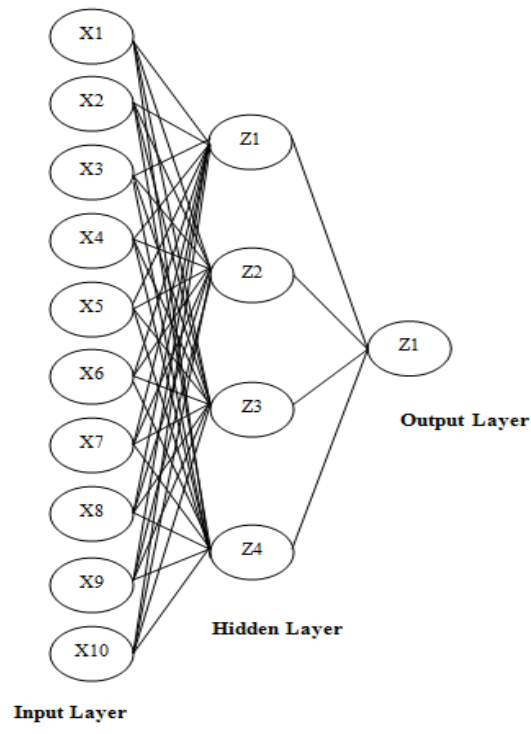

Gambar 2. Arsitektur Jaringan Identifikasi Penyakit ISPA 
ISSN 2614-5278 (media cetak), ISSN 2548-8368 (media online)

Available Online at https://ejurnal.stmik-budidarma.ac.id/index.php/mib

DOI 10.30865/mib.v5i3.3020

\section{HASIL DAN PEMBAHASAN}

\subsection{Analisis Logika Fuzzy}

Pada hasil pembahasan makalah ini proses akan dimulai dari analisis menggunakan Logika Fuzzy. dalam Fuzzy Inference System (FIS) identifikasi yang dilakukan adalah menentukan semesta pembicara untuk mengelompokan variabel berdasarkan data gejala yang sudah dihasilkan. Adapun tabel semesta pembicara dapat dilihat pada tabel 3 di bawah ini:

Tabel 3. Semesta Pembicara

\begin{tabular}{|c|c|c|c|}
\hline Variabel & Himpunan Fuzzy & $\begin{array}{c}\text { Semesta } \\
\text { Pembicaraan }\end{array}$ & Domain \\
\hline \multirow{4}{*}{ Hidung tersumbat } & Kurang Yakin & \multirow{3}{*}[0-100]{} & {$[0-50]$} \\
\hline & Cukup Yakin & & {$[30-70]$} \\
\hline & Sangat Yakin & & {$[50-100]$} \\
\hline & Kurang Yakin & \multirow{3}{*}{ [0 - -100] } & {$[0-50]$} \\
\hline \multirow[t]{3}{*}{ Pilek } & Cukup Yakin & & {$[30-70]$} \\
\hline & Sangat Yakin & & {$[50-100]$} \\
\hline & Kurang Yakin & \multirow{3}{*}[0-100]{} & {$[0-50]$} \\
\hline \multirow[t]{3}{*}{ Batuk } & Cukup Yakin & & {$[30-70]$} \\
\hline & Sangat Yakin & & {$[50-100]$} \\
\hline & Kurang Yakin & \multirow{3}{*}[0-100]{} & {$[0-50]$} \\
\hline \multirow[t]{3}{*}{ Sakit tenggorokan } & Cukup Yakin & & {$[30-70]$} \\
\hline & Sangat Yakin & & {$[50-100]$} \\
\hline & Kurang Yakin & \multirow{4}{*}[0-100]{} & {$[0-50]$} \\
\hline \multirow[t]{3}{*}{ Pegal-pegal } & Cukup Yakin & & {$[30-70]$} \\
\hline & Sangat Yakin & & {$[50-100]$} \\
\hline & Kurang Yakin & & {$[0-50]$} \\
\hline \multirow[t]{3}{*}{ Kelelahan } & Cukup Yakin & \multirow[t]{3}{*}[0-100]{} & {$[30-70]$} \\
\hline & Sangat Yakin & & {$[50-100]$} \\
\hline & Kurang Yakin & & {$[0-50]$} \\
\hline \multirow[t]{3}{*}{ Demam } & Cukup Yakin & \multirow[t]{3}{*}[0-100]{} & {$[30-70]$} \\
\hline & Sangat Yakin & & {$[50-100]$} \\
\hline & Kurang Yakin & & {$[0-50]$} \\
\hline \multirow[t]{3}{*}{ Sulit bernafas } & Cukup Yakin & \multirow[t]{3}{*}[0-100]{} & {$[30-70]$} \\
\hline & Sangat Yakin & & {$[50-100]$} \\
\hline & Kurang Yakin & & {$[0-50]$} \\
\hline \multirow[t]{3}{*}{ Pusing } & Cukup Yakin & \multirow[t]{3}{*}[0-100]{} & {$[30-70]$} \\
\hline & Sangat Yakin & & {$[50-100]$} \\
\hline & Kurang Yakin & & {$[0-50]$} \\
\hline \multirow{2}{*}{ Kehilangan kesadaran } & Cukup Yakin & \multirow[t]{2}{*}[0-100]{} & {$[30-70]$} \\
\hline & Sangat Yakin & & {$[50-100]$} \\
\hline
\end{tabular}

Setelah tabel 3 Semesta Pembicara pada FIS terbentuk, maka proses akan dilanjutkan pada tahapan pada Logika Fuzzy. Adapun tahapannya dapat dilihat berikut ini:

1. Tahapan Fuzzyfikasi

Fuzzifikasi yaitu suatu proses untuk mengubah suatu masukan dari bentuk nilai awal menjadi fuzzy (variabel linguistik) yang biasanya disajikan dalam bentuk himpunan-himpunan fuzzy dengan suatu fungsi kenggotaannya masing-masing. Fuzzyfikasi diharapkan dapat membantu menyederhanakan komputasi yang harus dilakukan oleh sistem tersebut dalam proses inferensinya. Berikut adalah fungsi keanggotaan dari grafik himpunan fuzzy pendiagnosa penyakit ISPA:

A. Variabel Hidung Tersumbat (X1)

Proses Fuzzyfikasi pada variabel (X1) dapat digambarkan pada kurva yang ada pada gambar 3 di bawah ini:

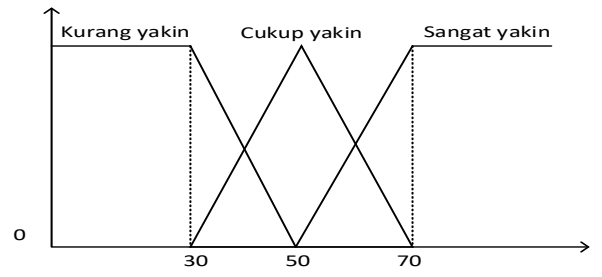

Gambar 3. Fungsi Keanggotaan Variabel (X1) 
Untuk proses Fuzzyfikasi pada variabel (X2) hingga seterusnya, lakukan langkah dan cara yang sama sesuai dengan ketentuan nilai keanggotaan berdasarkan tabel semesta pembicara sebelumnya.

\section{Tahapan Pembentukan Basis Pengetahuan}

Pada Tahapan ini, proses akan melakukan pembentukan rule berdasarkan variabel yang akan digunakan dalam proses identifikasi. Adapun hasil rule yang terbentuk sebanyak 32 rule yang akan menjadi aturan dalam proses identifikasi penyakit ISPA. Untuk melihat rule yang terbentuk, dapat dilihat berdasarkan sampel rule yang ada pada tabel 4 dibawah ini:

Tabel 4. Rule Identifikasi Penyakit ISPA

\begin{tabular}{|c|c|c|}
\hline Kode & Aturan & Then \\
\hline R01 & $\begin{array}{l}\text { IF (G01 is sangat yakin) AND (G02 is sangat yakin) AND (G03 is sangat yakin) } \\
\text { AND (G04 is sangat yakin) AND (G05 is sangat yakin) AND (G06 is sangat yakin) } \\
\text { AND (G07 is kurang yakin) AND (G08 is kurang yakin) AND (G09 is kurang yakin) } \\
\text { AND (G10 is kurang yakin) }\end{array}$ & $\begin{array}{c}\text { ISPA } \\
\text { RINGAN }\end{array}$ \\
\hline R02 & $\begin{array}{l}\text { IF (G01 is sangat yakin) AND (G02 is cukup yakin) AND (G03 is sangat yakin) } \\
\text { AND (G04 is sangat yakin) AND (G05 is sangat yakin) AND (G06 is sangat yakin) } \\
\text { AND (G07 is kurang yakin) AND (G08 is kurang yakin) AND (G09 is kurang yakin) } \\
\text { AND (G10 is kurang yakin) }\end{array}$ & $\begin{array}{c}\text { ISPA } \\
\text { RINGAN }\end{array}$ \\
\hline R03 & $\begin{array}{l}\text { IF (G01 is cukup yakin) AND (G02 is sangat yakin) AND (G03 is sangat yakin) } \\
\text { AND (G04 is sangat yakin) AND (G05 is sangat yakin) AND (G06 is sangat yakin) } \\
\text { AND (G07 is kurang yakin) AND (G08 is kurang yakin) AND (G09 is kurang yakin) } \\
\text { AND (G10 is kurang yakin) }\end{array}$ & $\begin{array}{c}\text { ISPA } \\
\text { RINGAN }\end{array}$ \\
\hline R04 & $\begin{array}{l}\text { IF (G01 is cukup yakin) AND (G02 is cukup yakin) AND (G03 is cukup yakin) AND } \\
\text { (G04 is cukup yakin) AND (G05 is cukup yakin) AND (G06 is cukup yakin) AND } \\
\text { (G07 is kurang yakin) AND (G08 is kurang yakin) AND (G09 is kurang yakin) AND } \\
\text { (G10 is kurang yakin) }\end{array}$ & $\begin{array}{c}\text { ISPA } \\
\text { RINGAN }\end{array}$ \\
\hline R05 & $\begin{array}{l}\text { IF (G01 is sangat yakin) AND (G02 is sangat yakin) AND (G03 is kurang yakin) } \\
\text { AND (G04 is kurang yakin) AND (G05 is kurang yakin) AND (G06 is kurang yakin) } \\
\text { AND (G07 is kurang yakin) AND (G08 is kurang yakin) AND (G09 is kurang yakin) } \\
\text { AND (G10 is kurang yakin) }\end{array}$ & $\begin{array}{c}\text { ISPA } \\
\text { RINGAN }\end{array}$ \\
\hline R06 & $\begin{array}{l}\text { IF (G01 is kurang yakin) AND (G02 is kurang yakin) AND (G03 is kurang yakin) } \\
\text { AND (G04 is kurang yakin) AND (G05 is kurang yakin) AND (G06 is kurang yakin) } \\
\text { AND (G07 is sangat yakin) AND (G08 is cukup yakin) AND (G09 is kurang yakin) } \\
\text { AND (G10 is kurang yakin) }\end{array}$ & $\begin{array}{c}\text { ISPA } \\
\text { BERAT }\end{array}$ \\
\hline R07 & $\begin{array}{l}\text { IF (G01 is kurang yakin) AND (G02 is kurang yakin) AND (G03 is kurang yakin) } \\
\text { AND (G04 is kurang yakin) AND (G05 is kurang yakin) AND (G06 is kurang yakin) } \\
\text { AND (G07 is cukup yakin) AND (G08 is sangat yakin) AND (G09 is kurang yakin) } \\
\text { AND (G10 is kurang yakin) }\end{array}$ & $\begin{array}{c}\text { ISPA } \\
\text { BERAT }\end{array}$ \\
\hline R08 & $\begin{array}{l}\text { IF (G01 is kurang yakin) AND (G02 is kurang yakin) AND (G03 is kurang yakin) } \\
\text { AND (G04 is kurang yakin) AND (G05 is kurang yakin) AND (G06 is kurang yakin) } \\
\text { AND (G07 is cukup yakin) AND (G08 is cukup yakin) AND (G09 is kurang yakin) } \\
\text { AND (G10 is kurang yakin) }\end{array}$ & $\begin{array}{c}\text { ISPA } \\
\text { BERAT }\end{array}$ \\
\hline R09 & $\begin{array}{l}\text { IF (G01 is kurang yakin) AND (G02 is kurang yakin) AND (G03 is kurang yakin) } \\
\text { AND (G04 is kurang yakin) AND (G05 is kurang yakin) AND (G06 is kurang yakin) } \\
\text { AND (G07 is sangat yakin) AND (G08 is sangat yakin) AND (G09 is sangat yakin) } \\
\text { AND (G10 is kurang yakin) }\end{array}$ & $\begin{array}{c}\text { ISPA } \\
\text { BERAT }\end{array}$ \\
\hline $\mathrm{R} 10$ & $\begin{array}{l}\text { IF (G01 is kurang yakin) AND (G02 is kurang yakin) AND (G03 is kurang yakin) } \\
\text { AND (G04 is kurang yakin) AND (G05 is kurang yakin) AND (G06 is kurang yakin) } \\
\text { AND (G07 is sangat yakin) AND (G08 is cukup yakin) AND (G09 is cukup yakin) } \\
\text { AND (G10 is kurang yakin) }\end{array}$ & $\begin{array}{c}\text { ISPA } \\
\text { BERAT }\end{array}$ \\
\hline
\end{tabular}

3. Tahapan Mesin Inferensi

Merupakan tahapan untuk membuktikan proses kinerja rule yang terbentuk dari proses sebelumnya. Proses ini dapat dilakukan dengan memberikan masukan nilai pada setiap variabel yang digunakan. Adapaun proses yang didapat dalam tahapan ini dapat dilihat berdasarkan pegujian yang dilakukan dengan percobaan dari Seorang pasien memiliki gejala sebagai berikut, hidung tersumbat 75 , pilek 72 batuk 80, sakit tenggorokan 83, pegal-pegal 85 , kelelahan 28 , demam 28 , sulit bernafas 32 , pusing 36 , kehilangan kesadaran 28 . Setelah nilai input diberikan maka Fuzzy akan melakukan proses pengujian untuk memberikan keluaran yang dihasilkan. 
ISSN 2614-5278 (media cetak), ISSN 2548-8368 (media online)

Available Online at https://ejurnal.stmik-budidarma.ac.id/index.php/mib DOI 10.30865/mib.v5i3.3020

4. Tahap Defuzzyfikasi

Dalam proses Defuzzyfikasi yang akan dilakukan, proses tersebut akan menggunakan perhitungan dalam persamaan 2 berikut ini :

$$
\begin{gathered}
z=\frac{\sum_{i=1}^{n} w i z i}{w i} \\
z=\frac{(0 * 1)+(0 * 1)+(0 * 1)+\ldots+(0.7 * 0.8)+\ldots+(0 * 0.4)}{0+0+0+\ldots 0.7+\ldots+0} \\
z=\frac{0.56}{0.7}=0.8
\end{gathered}
$$

Dari hasil perhitungan proses Defuzzyfikasi, Hasil yang diperoleh sebesar 0.8 dimana tahap defuzzyfikasi diatas menunjukkan diagnosa ISPA ringan. Dengan demikian hasil diagnosis dari kasus diatas adalah ISPA Ringan.

\subsection{Analisis Identifikasi Penyakit ISPA dengan ANN}

Setelah proses analisis dengan menggunakan Logika Fuzzy, proses identifikasi akan dilanjutkan dengan menggunakan ANN. Tahapan proses analisis ANN akan diawali dengan melakukan transformasi data dengan menggunakan Persamaan.1 yang sudah dijelaskan diawal. Data yang akan ditranformasi ini didapat dari proses Fuzzy diawal. Adapun hasil transformasi yang sudah dihasilkan dapat dilihat pada Tabel.5 dibawah ini :

Tabel 5. Hasil Transformasi Data ANN

\begin{tabular}{ccccccccccc}
\hline $\mathrm{X} 1$ & $\mathrm{X} 2$ & $\mathrm{X} 3$ & $\mathrm{X} 4$ & $\mathrm{X} 5$ & $\mathrm{X} 6$ & $\mathrm{X} 7$ & $\mathrm{X} 8$ & $\mathrm{X} 9$ & $\mathrm{X} 10$ & $\mathrm{~T}$ \\
\hline 0.9000 & 0.8529 & 0.8529 & 0.8435 & 0.9000 & 0.8812 & 0.4765 & 0.3824 & 0.4294 & 0.3824 & 0.1000 \\
0.8529 & 0.6647 & 0.9000 & 0.8529 & 0.8529 & 0.9000 & 0.6176 & 0.6647 & 0.6271 & 0.5706 & 0.1000 \\
0.6647 & 0.9000 & 0.8624 & 0.8906 & 0.8529 & 0.9282 & 0.3447 & 0.2882 & 0.1941 & 0.3259 & 0.1000 \\
0.6176 & 0.6647 & 0.6176 & 0.7118 & 0.6647 & 0.5706 & 0.2882 & 0.3824 & 0.3353 & 0.2882 & 0.1000 \\
0.8529 & 0.9000 & 0.4765 & 0.3824 & 0.4765 & 0.3353 & 0.2882 & 0.2882 & 0.3824 & 0.3353 & 0.1000 \\
0.2882 & 0.3353 & 0.2882 & 0.3353 & 0.3353 & 0.3353 & 0.8529 & 0.6647 & 0.2882 & 0.3353 & 0.9000 \\
0.3353 & 0.2788 & 0.3071 & 0.3824 & 0.2882 & 0.3353 & 0.6647 & 0.9000 & 0.3824 & 0.3353 & 0.9000 \\
0.2882 & 0.3353 & 0.3353 & 0.3353 & 0.2788 & 0.2412 & 0.6647 & 0.6176 & 0.2882 & 0.2882 & 0.9000 \\
0.2882 & 0.2412 & 0.2882 & 0.2882 & 0.3353 & 0.3353 & 0.9000 & 0.8529 & 0.8529 & 0.2882 & 0.9000 \\
0.2882 & 0.2412 & 0.2412 & 0.3353 & 0.3353 & 0.2882 & 0.8529 & 0.6647 & 0.6176 & 0.2882 & 0.9000 \\
\hline
\end{tabular}

Setelah dilakukan proses transformasi pada data, tahap selanjutnya adalah melakukan proses pelatihan dan pengujian pada jaringan. Proses ini dilakukan dengan mengadopsi aturan yang dihasilkan dari proses sebelumnya untuk diuji kembali dengan menggunakan ANN. Adapun hasil proses tersebut dapat disajikan pada tabel 6 di bawah ini:

Tabel 6. Hasil Pelatihan dan Pengujian Jaringan

\begin{tabular}{cccc}
\hline Pola Jaringan & MSE & MAPE & Akurasi \\
\hline Pola 10-4-1 & 0.009902 & 8.516263 & 91.48374 \\
Pola 10-7-1 & 0.009879 & 8.429088 & 91.57091 \\
Pola 10-10-1 & 0.009555 & 8.291709 & 91.70829 \\
Pola 10-15-1 & 0.009182 & 8.036776 & 91.96322 \\
Pola 10-20-1 & 0.00961 & 8.147091 & 91.85291 \\
\hline
\end{tabular}

Berdasarkan Tabel.6 yang disajikan diatas, dapat dilihat bahwa jaringan yang terbaik dalam melakukan proses identifikasi pada penyakit ISPA berada pada pola jaringan dengan pola 10-15-1. Pola ini menyajikan nilai rata rata kesalahan berdasarkan MSE sebesar 0.00912 dan MAPE sebesar 8.036776\%. serta nilai akurasi sebesar $91.96 \%$.

Untuk melihat hasil pengujian dari proses identifikasi pada penyakit ISPA yang sudah dilakukan, dapat dilihat pada tabel 7 di bawah ini:

Tabel 7. Hasil Identifikasi Penyakit ISPA

\begin{tabular}{rr}
\hline Target & Y_Output \\
\hline 0.1000 & 0.0658 \\
0.1000 & 0.0201 \\
0.1000 & 0.2143 \\
0.1000 & 0.2593 \\
0.1000 & 0.0644 \\
\hline
\end{tabular}


ISSN 2614-5278 (media cetak), ISSN 2548-8368 (media online)

Available Online at https://ejurnal.stmik-budidarma.ac.id/index.php/mib DOI 10.30865/mib.v5i3.3020

\begin{tabular}{rr}
\hline Target & Y_Output \\
\hline 0.9000 & 0.9412 \\
0.9000 & 0.8516 \\
0.9000 & 0.9608 \\
0.9000 & 0.8649 \\
0.9000 & 0.9421 \\
\hline
\end{tabular}

Dari tabel 7 di atas, menunjukan bahwa hasil output jaringan identifikasi penyakit ISPA menyajikan hasil yang cukup tepat dan akurat. tidak hanya tabel hasil identifikasi, adapun grafik proses analisis ANN juga menunjukan hasil yang optimal yang dapat dilihat pada gambar 4 di bawah ini:

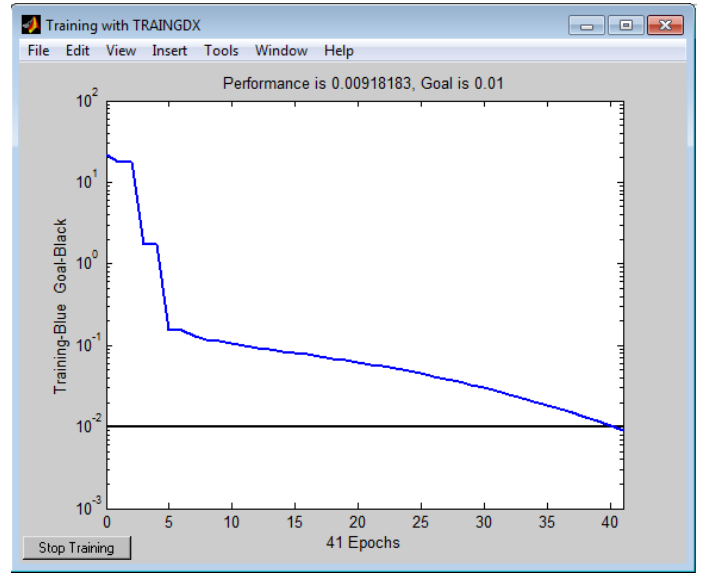

Gambar 4. Analisis ANN

Berdasarkan gambar 4 di atas, menjelaskan bahwa ANN memberikan hasil analisis yang cukup baik dalam proses identifikasi dengan hasil perhitungan pembelajaran terawasi. Dari proses identifikasi ini, dapat dilihat bahwa model identifikasi yang dikembangkan dengan menggunakan konsep logika Fuzzy dan ANN dapat memberikan sebuah proses yang kompleks dalam menentukan penyakit ISPA. Hasil yang diberikan sudah cukup membuktikan bahwa model ini dapat memaksimalkan proses identifikasi sebelumnya. Nilai akurasi yang dihasilkan dari prose komparasi berdasarkan keluaran dengan melakukan perbandingan dengan proses manual sudah dapat membuktikan kebenaran dari kerja proses identifikasi yang dilakukan. Sehingga keluaran jaringan memberikan ketepatan nilai untuk dijadikan sebuah keputusan dalam menentukan penyakit ISPA.

\section{KESIMPULAN}

Model identifikasi dengan Fuzzy Neural Network (FNN) dapat dikembangkan untuk melakukan proses penentuan penyakit ISPA. Proses pembahasan dalam model ini cukup efektif menyempurnakan bentuk identifikasi sebelumnya sehingga hasil yang diberikan cukup optimal. Berdasarkan pembahasan, Logika Fuzzy mampu digunakan untuk memberikan kepastian pada data dan aturan identifikasi yang bersifat kabur sehingga proses identifikasi pada penyakit ISPA yang dilakukan ANN akan dapat memberikan hasil yang maksimal. Kombinasi kedua konsep yang dikembangkan pada model identifikasi ini sangat efektif untuk menyajikan sebuah proses diagnosa yang didasari dari Knowladge Based System yang didapat dari Fuzzy Inference System. Tujuan yang dicapai dalam pembahasan ini adala melakukan pengembangan pada sebuah model identifikasi yang tersktruktur untuk menghasilkan keluaran yang cukup baik. Manfaat yang didapat adalah memberikan sebuah informasi secara dini untuk pencegahan agar terhindar dari penyakit ISPA.

\section{REFERENCES}

[1] Yuyun Priwahyuni, E. feroza Sinaga, Christine Vita Gloria, Agus Alamsyah, Ikhtiyaruddin Ikhtiyaruddin, and Iqlima Afif Azizah, "Cegah Penyakit ISPA di Puskesmas Kecamatan Limapuluh Kota Pekanbaru," J. Pengabdi. UntukMu NegeRI, vol. 4, no. 1, pp. 54-59, 2020, doi: 10.37859/jpumri.v4i1.1829.

[2] T. F. Ramadhani, I. Fitri, and E. T. E. Handayani, "Sistem Pakar Diagnosa Penyakit ISPA Berbasis Web Dengan Metode Forward Chaining," JOINTECS (Journal Inf. Technol. Comput. Sci., vol. 5, no. 2, p. 81, 2020, doi: 10.31328/jointecs.v5i2.1243.

[3] A. M. Yunita and S. Susilawati, "Aplikasi Prediksi Penyebaran Penyakit Infeksi Saluran Pernafasan Akut (ISPA) Di Kabupaten Pandeglang," J. Tek. Inform. UNIS, vol. 7, no. 2, pp. 109-114, 2020, doi: 10.33592/jutis.v7i2.391.

[4] N. Latifatul A., "Hubungan Lingkungan Fisik Rumah dengan Kejadian Penyakit ISPA Pada Balita di desa Guyung Kecamatan Gerih Kabupaten Ngaw," Hub. Lingkung. Fis. Rumah dengan Kejadian Penyakit ISPA Pada Balita di desa Guyung Kec. Gerih Kabupaten Ngaw, p. 116, 2019.

[5] N. Khuriyah, "Hubungan Antara Riwayat Penyakit Ispa Dan Diare Dengan Status Gizi Pada Anak Di Wilayah Kerja 
JURNAL MEDIA INFORMATIKA BUDIDARMA

Volume 5, Nomor 3, Juli 2021, Page 870-878

ISSN 2614-5278 (media cetak), ISSN 2548-8368 (media online)

Available Online at https://ejurnal.stmik-budidarma.ac.id/index.php/mib

DOI 10.30865/mib.v5i3.3020

Puskesmas Kaliwungu Kabupaten Kudus,” Pros. HEFA 1st 2017, 2017.

[6] Y. Yuliana, P. Paradise, and K. Kusrini, "Sistem Pakar Diagnosa Penyakit Ispa Menggunakan Metode Naive Bayes Classifier Berbasis Web," CSRID (Computer Sci. Res. Its Dev. Journal), vol. 10, no. 3, p. 127, 2021, doi: 10.22303/csrid.10.3.2018.127-138.

[7] Edi Iskandar, "Sistem Pakar Untuk Diagnosa Penyakit ISPA Menggunakan Metode Faktor Kepastian," J. Ilm. STMIK GI MDP, vol. 3, no. Sistem Pakar, pp. 9-16, 2007.

[8] B. Sasangka and A. Witanti, "Sistem Pakar Diagnosa Penyakit Infeksi Saluran Pernafasan Akut Pada Anak Menggunakan Teorema Bayes," JMAI (Jurnal Multimed. Artif. Intell., vol. 3, no. 2, pp. 45-51, 2019, doi: 10.26486/jmai.v3i2.83.

[9] S. Arifin, M. A. Muslim, and S. Sugiman, "Implementasi Logika Fuzzy Mamdani untuk Mendeteksi Kerentanan Daerah Banjir di Semarang Utara," Sci. J. Informatics, vol. 2, no. 2, p. 179, 2016, doi: 10.15294/sji.v2i2.5086.

[10] H. Hardianto and N. Nurhasanah, "Identifikasi Penyakit pada Sel Darah Menggunakan Logika Fuzzy Mamdani," Prism. Fis., vol. 7, no. 3, p. 269, 2020, doi: 10.26418/pf.v7i3.38106.

[11] A. M. NUGRAHENI, "Sistem Pakar Deteksi Dini Tingkat Risiko pada Ibu Hamil terhadap Preeklampsia dengan Logika Fuzzy," Perpust. Univ. Airlangga, pp. 1-198, 2016, [Online]. Available: http://repository.unair.ac.id/56050/.

[12] B. Setia and P. T. Prasetyaningrum, Penerapan Metode Logika Fuzzy, vol. 2, no. 1. 2019.

[13] S. Kiranyaz, T. Ince, A. Iosifidis, and M. Gabbouj, "Operational neural networks," Neural Comput. Appl., vol. 32, no. 11, pp. 6645-6668, 2020, doi: 10.1007/s00521-020-04780-3.

[14] P. K. Vadla, A. Ruwali, K. B. Prakash, M. V. P. Lakshmi, and G. R. Kanagachidambaresan, "Neural Network," in EAI/Springer Innovations in Communication and Computing, 2021, pp. 39-43.

[15] R. Bala and D. Kumar, "Classification Using ANN: A Review," Int. J. Comput. Intell. Res., vol. 13, no. 7, pp. 18111820, 2017, [Online]. Available: http://www.ripublication.com.

[16] E. Y. Puspaningrum, L. S. Qolby, and Y. V. Via, "OPTIMASI JARINGAN SARAF TIRUAN UNTUK DIAGNOSIS PENYAKIT DIABETES INDIAN PIMA,” Teknologi, vol. 6, no. 1, p. 49, 2016, doi: 10.26594/teknologi.v6i1.560.

[17] L. Listyalina, E. L. Utari, and D. E. Puspaningtyas, "PENENTUAN PENYAKIT PARU DENGAN MENGGUNAKAN JARINGAN SARAF TIRUAN," Simetris J. Tek. Mesin, Elektro dan Ilmu Komput., vol. 11, no. 1, pp. 233-240, 2020, doi: 10.24176/simet.v11i1.3667.

[18] D. A. Dharmawan, "Deteksi Kanker Serviks Otomatis Berbasis Jaringan Saraf Tiruan LVQ dan DCT," Jnteti, vol. 03, no. 04 , pp. 269-272, 2014.

[19] Z. A. Leleury and S. N. Aulele, "Perancangan Sistem Diagnosa Penyakit Saluran Pernapasan Menggunakan Metode Learning Vector Quantization (LVQ)," J. Mat. Integr., vol. 12, no. 1, p. 1, 2017, doi: 10.24198/jmi.v12.n1.10247.1-10.

[20] A. Setiawan, B. Yanto, and K. Yasdomi, LOGIKA FUZZY Dengan MATLAB (Contoh Kasus Penelitian Penyakit Bayi dengan Fuzzy Tsukamoto), vol. 1, no. March. 2018.

[21] B. Y. A. Setiawan, Logika Fuzzy Dengan Matlab, vol. 1, no. 13508029. 2018

[22] S. Sukamto, "Pengendalian Kecepatan Motor Induksi Menggunakan Kontroller Logika Fuzzy," JEECAE (Journal Electr. Electron. Control. Automot. Eng., vol. 4, no. 1, pp. 245-252, 2019, doi: 10.32486/jeecae.v4i1.330.

[23] W. Katrina, H. J. Damanik, F. Parhusip, D. Hartama, A. P. Windarto, and A. Wanto, "C.45 Classification Rules Model for Determining Students Level of Understanding of the Subject," in Journal of Physics: Conference Series, 2019, vol. 1255, no. 1, doi: 10.1088/1742-6596/1255/1/012005.

[24] E. A. Banurea, M. Syahrizal, and Murdani, "Jaringan Syaraf Tiruan untuk Memprediksi Jumlah Permintaan Pemasangan Indihome Dengan Metode Backpropagation," J. Pelita Inform., vol. 17, no. 1, pp. 179-184, 2018.

[25] N. Amalia, E. W. Hidayat, and A. P. Aldya, "Pengenalan Aksara Sunda Menggunakan Metode Jaringan Saraf Tiruan Backpropagation Dan Deteksi Tepi Canny," CESS (Journal Comput. Eng. Syst. Sci., vol. 5, no. 1, p. 19, 2020, doi: 10.24114/cess.v5i1.14839. 